\section{Nauplius}

The Journal of The

Brazilian Crustacean Society

e-ISSN 2358-2936

www.scielo.br/nau www.crustacea.org.br

\title{
Mysidopsis gemina n. sp. (Crustacea: Mysida: Mysidae) from the northern Pacific coast of Costa Rica
}

W. Wayne Price ${ }^{1}$ (D) orcid.org/0000-0001-7351-1563

Richard W. Heard ${ }^{2}$

Rita Vargas ${ }^{3}$

1 Department of Biology, University of Tampa. Tampa, Florida 33606, USA. WWP E-mail: wprice@ut.edu

2 Department of Coastal Sciences, University of Southern Mississippi. Ocean Springs, Mississippi 39566, USA.

RWH E-mail: richard.heard@usm.edu

3 University of Costa Rica, School of Biology. 11501-2060 San Jose, Costa Rica.

RV E-mail: rita.vargas@ucr.ac.cr

ZOOBANK: http://zoobank.org/urn:lsid:zoobank.org:pub:BAF9A25E-5B27-4D04BDBA-B04A9C531ED6E2F

\section{Abstract}

Mysidopsis gemina $\mathrm{n}$. sp. is described from protected and exposed beach habitats in the provinces of Puntarenas and Guanacaste on the northern Pacific coast of Costa Rica. Morphologically, M. gemina most closely resembles M. furca Bowman, 1957 known from the Atlantic and Gulf Coasts of North America. Both these species are unique within the genus by their distinctively sexually dimorphic telsons. The new Costa Rican species can be distinguished from M. furca and other species of Mysidopsis by a combination of having a male with biarticulated endopods on the first pleopods and pleopods 2-5 with large plate-like pseudopodia (exites). The occurrence of these characters and morphological features within the subfamily Leptomysinae is discussed.

\section{KEYWORDS}

Mysid, eastern Pacific, Central America, taxonomy, new species, Peracarida.
CORRESPONDING AUTHOR William Wayne Price wprice@ut.edu

SUBMITTED 29 April 2019 ACCEPTED 08 September 2019 PUBLISHED 02 December 2019

DOI 10.1590/2358-2936e2019016

\section{(cc) BY}

All content of the journal, except where identified, is licensed under a Creative Commons attribution-type BY.

Nauplius, 27: e2019016 


\section{INTRODUCTION}

To date, only four species of mysids belonging to the family Mysidae have been documented from the Pacific coastal waters of Costa Rica (Price, 2004; Price et al., 2009). Tattersall (1951) described Antromysis anophelinae W. Tattersall, 1951 from burrows of the land crab Cardisoma crassum Smith, 1870 in the province of Puntarenas. Heteromysis panamaensis O. Tattersall, 1967 was described from the coast of Guanacaste in depths of 5-18 $\mathrm{m}$ from sandy/shelly substrates and found on occasion in gastropod shells harboring hermit crabs. Neither of these species has been reported since their original descriptions. Chlamydopleon (=Bowmaniella) banneri (Băcescu, 1968) was reported from sandy beaches of Puntarenas by Dexter (1974) and from Puntarenas and Guanacaste by Heard and Price (2006) (see Wittmann, 2009). In the same study of sandy beach fauna of Costa Rica and Colombia, Dexter (1974) recorded Metamysidopsis sp. from Guanacaste.

During collections of malacostracan crustaceans and other invertebrates from the beaches and shallow bays of the provinces of Puntarenas and Guanacaste on the Pacific coast of northern Costa Rica, an undescribed species of the mysid belonging to the genus Mysidopsis G.O. Sars, 1864 was discovered. The description of this new species is presented herein.

\section{Material and Methods}

Mysids were sampled from exposed and protected beaches of Puntarenas and Guanacaste in September 2010, April 2012, and March 2014. Specimens of the new species were collected at a depth of 0.5 to $1.0 \mathrm{~m}$ using a hand-held $0.9 \mathrm{~mm}$ mesh bottom "kicknet", preserved in a 3\% formalin-seawater solution, and later transferred to $70 \%$ ethanol for examination. Body length was determined as being the distance from the anterior margin of the carapace to the posterior margin of the telson, excluding setae. Type material and additional specimens are deposited in the University of Costa Rica, School of Biology, Zoology Museum (MZUCR) and the Gulf Coast Research Laboratory (GCRL).

\section{Systematics}

Order Mysida Boas, 1883

Family Mysidae Haworth, 1825

Subfamily Leptomysinae Czerniavsky, 1882

Tribe Mysidopsini Wittmann, Ariana and

Lagardère, 2014

Genus Mysidopsis G.O. Sars, 1864

Mysidopsis gemina n. sp.

(Figs. 1-3)

Type material. Holotype: adult male (length [L] $6.4 \mathrm{~mm}$ ), Costa Rica, Puntarenas, Playa Caldera,

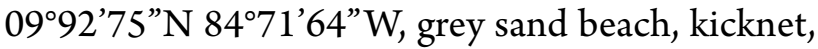
intertidal zone, depth $1.0 \mathrm{~m}$, R. Heard, O. Breedy and R. Vargas coll., 15 Sep 2010, MZUCR 2843-02. — Paratypes: 1 adult male (L $5.1 \mathrm{~mm}$ ), 4 ovigerous females (L 5.0, 5.1, 5.5, $5.4 \mathrm{~mm}$ ), same collection data as holotype, MZUCR 2843-03; 2 adult males (L 6.2, $5.9 \mathrm{~mm}$ ), Costa Rica, Puntarenas, Playa Caldera, 09 $92^{\prime} 75^{\prime} \mathrm{N} 84^{\circ} 71^{\prime} 64^{\prime} \mathrm{W}$, grey sand beach, kicknet, intertidal zone, depth $0.5 \mathrm{~m}, \mathrm{R}$. Heard and R. Vargas coll., 12 Sep 2010, MZUCR 2817-02; 2 adult males (L 5.4, $5.1 \mathrm{~mm}$ ), 2 ovigerous females (L 5.4, $5.5 \mathrm{~mm}$ ), same collection data as holotype, GCRL 6601.

Additional material examined. 8 males, 15 ovigerous females, 7 non-ovigerous females, Costa Rica, Puntarenas, Playa Caldera, 0992'75”N 8471'64”W, grey sand beach, kicknet, intertidal zone, depth $0.5 \mathrm{~m}$, R. Heard and R. Vargas coll., 12 Sep 2010, MZUCR 2817-01; 3 males, 1 non-ovigerous female, Costa Rica, Guanacaste, Bahía Culebra, Playa Panama, $10^{\circ} 35^{\prime 2} 27.6^{\prime} \mathrm{N} 85^{\circ} 39^{\prime} 32.4^{\prime \prime} \mathrm{W}$, grey sand beach, kicknet, intertidal zone, depth $1.0 \mathrm{~m}$, R. Heard, O. Breedy and R. Vargas coll., 14 Sep 2010, MZUCR 2822-1; 5 males, 12 ovigerous females, 11 non-ovigerous females, Puntarenas, Costa Rica, Playa Caldera, 0992'75”N $84^{\circ} 71^{\prime} 6$ "W, grey sand beach, kicknet, intertidal zone, depth $1.0 \mathrm{~m}, \mathrm{R}$. Heard, O. Breedy and R. Vargas coll., 15 Sep 2010, MZUCR 2843-01; 2 males, 3 ovigerous females, Costa Rica, Guanacaste, Playa Ocotal, 
$10^{\circ} 32$ '52.8” $\mathrm{N} 85^{\circ} 43^{\prime} 19.2^{\prime} \mathrm{W}$, rocky area, intertidal, algal washings, Mar 2014, R. Heard, O. Breedy and R. Vargas coll., MZUCR 3122-02; 1 ovigerous female, Costa Rica, Puntarenas, Cabo Blanco, Poza San Miguel, $09^{\circ} 34^{\prime} 40.8^{\prime \prime} \mathrm{N}, 85^{\circ} 8^{\prime} 16.8^{\prime}$ W, tide pools at night with light, kicknet, R. Vargas and A. Carrillo, 21 Apr 2012, MZUCR 3240-01.

Diagnosis. Antennal scale lanceolate, apex rounded with indistinct suture; carapace with anterior margin produced into an acutely pointed triangular rostrum reaching mid-length to distal end of article 1 of antennular peduncle; carpopropodus of thoracic endopods 3-8 3-articulated; male pleopod 1 with 2 -articulated linguiform endopod; male pleopods 2-5 with enlarged membraneous, transparent pseudobranchial lobes (exites) on basal article of endopods; telson entire, linguiform, with rounded to truncate apex; marked sexual dimorphism, female, lateral margins with 17-20 short spiniform setae, increasing in length posteriorly, apex with two pairs of subequal, long, stout spiniform setae, outer pair curved inward, inner pair straight to slightly curved, about 0.3 length of telson; outer-most apical setae 1.7-2.2 times length of most posterior lateral setae; male, lateral margins with 20-23 short spiniform setae, increasing in length posteriorly; apex with three pairs of fairly stout spiniform setae, inner-most pairs subequal in length; about 0.2 length of telson; outer-most apical pair 1.4-1.7 times length of most posterior lateral setae; uropodal endopod with 16-20 spiniform setae along inner median margin from region of statocyst to apex.

Description. General body form (Fig. 1A): moderately slender, adult males to $6.4 \mathrm{~mm}$ and females to $5.5 \mathrm{~mm}$; carapace with anterior margin produced into an acutely pointed triangular rostrum extending mid-length to distal end of article 1 of the antennular peduncle; posterior dorsal margin broadly emarginate, partially exposing thoracic somite 8 ; antero-lateral corners rounded.

Eyes (Fig. 1A): cornea large, globular, broader than eyestalk, occupying distal $45 \%$ of eye, extending to article 2 of antennular peduncle.
Antennular peduncle (Fig. 1B): more robust in males than females, shorter than antennal scale; article 1 subequal in length with article 3 , disto-lateral epiprocess with 3-5 plumose setae, apophysis near disto-medial margin with 5-9 plumose setae; article 2 short, with 8-9 slender simple (smooth) and plumose setae and 1 blade-like plumose seta on disto-medial margin; article 3 with one long simple seta and one short plumose seta mid-lateral; group of 4-5 long simple setae on disto-medial margin; distal border with dorso-medial lobe bearing two tooth-like processes and 3-5 plumose setae; male lobe (appendix masculina) large and densely setose with no indentation on medial margin; outer antennular flagellum slightly thicker than inner.

Antenna (Fig. 1C): scale lanceolate, extending well beyond peduncle, 5.5-7 times as long as maximum width; outer margin slightly concave to straight; inner margin slightly convex; apex with indistinct suture, tip about 0.15 scale length; all margins setose; peduncle 3-articulated; article 1 (not shown in Fig. 1C) slightly shorter than article 3 and about half as long as article 2; article 2 with 1 long and 2 short plumose setae on inner distal margin and 1 simple seta on outer distal margin; article 3 with 2 long simple setae and 3-4 shorter plumose setae on inner distal margin and 2 simple setae along outer distal margin; sympod with small tooth on distolateral corner.

Labrum (Fig. 1D): well rounded, wider than long, middle half of bilobed posterior margin with cluster of short fine setae on one side of emargination and short coarse setae on the other.

Mandibles (Fig. 1E): palp 3-articulated; article 1 small with no setae, article 2 with mostly simple setae on outer, inner, and distal margins; article 3 about 0.6 times as long as article 2 , mostly with simple setae, but distal half with a long, curved spiniform seta armed bilaterally in mid-part with barbs, and 7-9 shorter spiniform setae with similar barbs along their entire lengths.

Gnathobasic surfaces of both mandibles without molar process; left mandible, incisor process with 6-7 teeth, lacinia mobilis with 5-6 teeth, spine row with three teeth and series of smaller spine-like teeth and bristles; right mandible, incisor process with 5-6 teeth, lacinia mobilis spherical process with 4 teeth, spine 

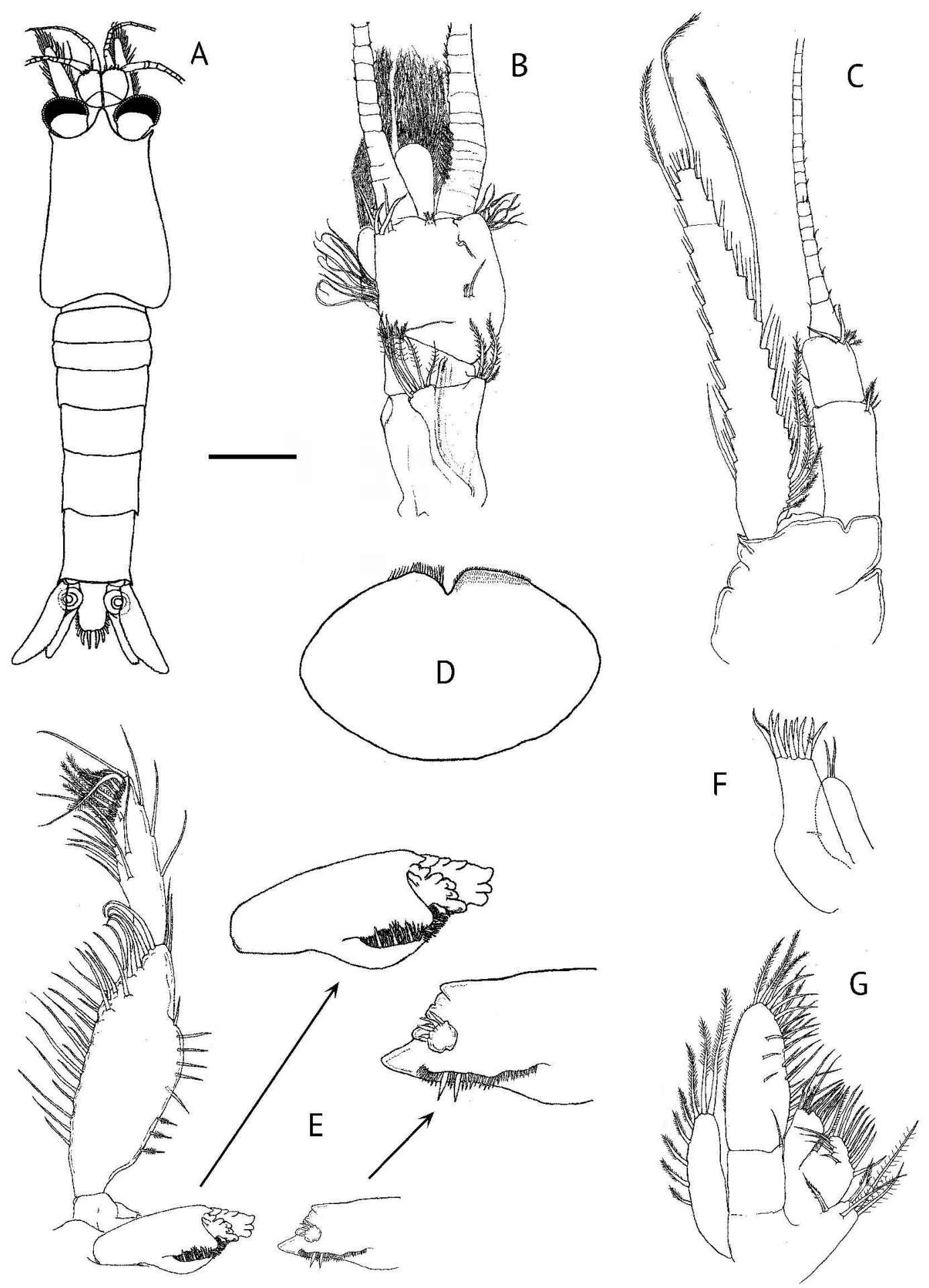

Figure 1.Mysidopsis gemina n. sp., adult female (A), male (B-G). A, Dorsal view; B, antennular peduncle; C, antennal peduncle and scale; D, labrum; E, mandibles, anterior (rostral) view, with enlargement of gnathobasic surfaces; F, maxillule; G, maxilla. Scale: A, $0.5 \mathrm{~mm}$; B, C, $0.2 \mathrm{~mm}$; E-G, $0.1 \mathrm{~mm}$; D, $0.5 \mathrm{~mm}$. 
row with 2 large teeth and series of smaller teeth and bristles.

Maxillule (Fig. 1F): outer lobe apex with 9 strong serrate setae; inner lobe with two apical microserrated setae and one medial microserrated seta along outer margin.

Maxilla (Fig. 1G): exopod relatively narrow, with 7-9 plumose setae; endopod 2-articulated, distal article oval, about 2.4 times as long as wide, with 3 submarginal simple setae and series of simple and plumose setae along apex and inner margin; coxal endite with 2-3 plumose and 2 barbed setae; basal endite bilobed, with simple and plumose setae and 1 serrate seta on inner margins.

Thoracic endopods: endopod length increases in order of endopods 1, 2, (6, 7, 8 subequal), 5, (3, 4 subequal) (Figs. 2A-G, 3A); thoracic endopod 1 (Fig. 2A): short and robust, typical of genus; ischium and merus fused (merischium), two times carpus length, slightly shorter than combined propodus and dactylus lengths, smooth setae along medial margin; carpus with 2-5 simple setae on medial margin, three serrate setae along lateral margin; propodus bent inward, several simple setae and one serrate seta on distolateral margin, 2-4 simple setae on disto-medial corner; dactylus densely setose with simple setae, strong curved terminal seta; thoracic endopod 2 (Fig. $2 \mathrm{~B})$ : ischium $0.7-0.8$ length of merus; merus slightly shorter than carpopropodus, with one serrate and one simple seta on distolateral corner; carpopropodus with one strong pectinate and one plumose seta on disto-lateral corner; dactylus with three strong pectinate setae and two plumose setae on disto-lateral margin and inner face, strong curved terminal seta; thoracic endopods 3-8 (Figs. 2C-G, 3A): ischium length as compared to merus length decreases steadily from 1.4 (endopod 3 ) to 0.9 (endopod 8); merus 1.1-1.4 times as long as carpopropodus, one serrate seta on disto-lateral corner (Fig. 2C); carpopropodus 3-articulated; middle article $0.4-0.8$ length of other two articles, one serrate seta on disto-lateral corner of proximal two articles except endopod 8; dactylus with undulating medial margin, armed with strong, curved terminal seta.

Penes: (not figured) length $0.8-1.1$ basal plate length of exopod of thoracopod 8; well developed, cylindrical, each penis with two apical lobes, one with two large simple setae, outer face with series of 10 plumose setae.

Thoracic exopods: basal plates with small tooth on outer distal corner; exopod 1 with 8 articles, exopods 2-8 with 9 articles (Fig. 2B)

Pleopods: female, uniarticulate setose plates (Fig. 3B, C); pleopod 5 longest, reaching about 0.6 length of abdominal somite 5; male pleopods well developed; pleopod 1 (Fig. 3D, E), 2-articulated endopod linguiform with 1 distal simple seta; article 1 with pseudobranchial lobe (exite) normally developed with 4-5 setulose setae; anterior face with group of 7-10 simple setae; exopod 8-articulated, about three times length of endopod; pleopods $2-5$ biramous, endopods and exopods 8-articulated; pseudobranchial lobes enlarged, membraneous and transparent with 5 setulose setae; pleopod 4 (Fig. 3F), exopod with terminal article having 1 simple subapical seta and one long barbed apical spiniform seta as long as the 4-5 distal articles combined.

Telson (Fig. 3G, H): entire, linguiform, 1.4-1.6 times as long as wide at base, about 0.8 length of last abdominal somite; lateral margins moderately concave, apex rounded to truncate; marked sexual dimorphism, female, lateral margins with 17-20 short spiniform setae, increasing in length posteriorly, apex with two pairs of subequal, long, stout spiniform setae, outer pair curved inward, inner pair straight to slightly curved, about 0.3 length of telson; outer-most apical setae 1.72.2 length of most posterior lateral setae; male, lateral margins with 20-23 short spiniform setae, increasing in length posteriorly; apex with three pairs of fairly stout spiniform setae, inner-most pairs subequal in length; about 0.2 length of telson; outer-most apical pair 1.4-1.7 length of most posterior lateral setae.

Uropod (Fig. 3I): exopod 1.2-1.3 times as long as endopod, 1.4-1.5 times as long as telson, outer margin straight to slightly concave, inner margin convex; endopod 1.1-1.3 times as long as telson, outer and inner margins slightly concave and setose, inner margin with 16-20 mostly subequal spiniform setae from region of statocyst to apex.

Colour (in preserved specimens): body uniformly brown to beige with diffuse brown pigmentation irregularly distributed on eyestalks, carapace, thorax, abdomen, telson, and appendages; heavy pigmentation near posterior ventral margins of abdominal somites, 

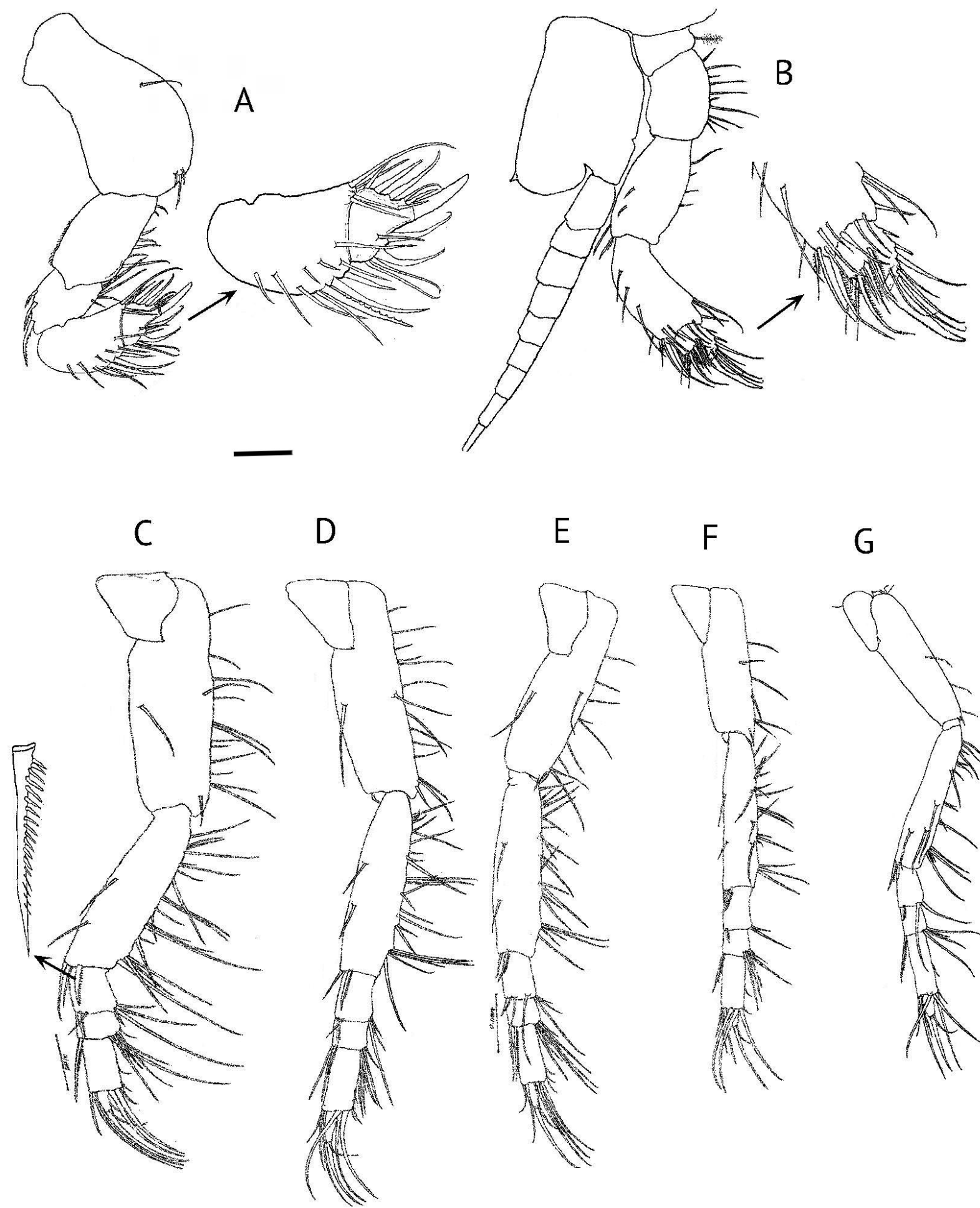

$\mathrm{F}$

G
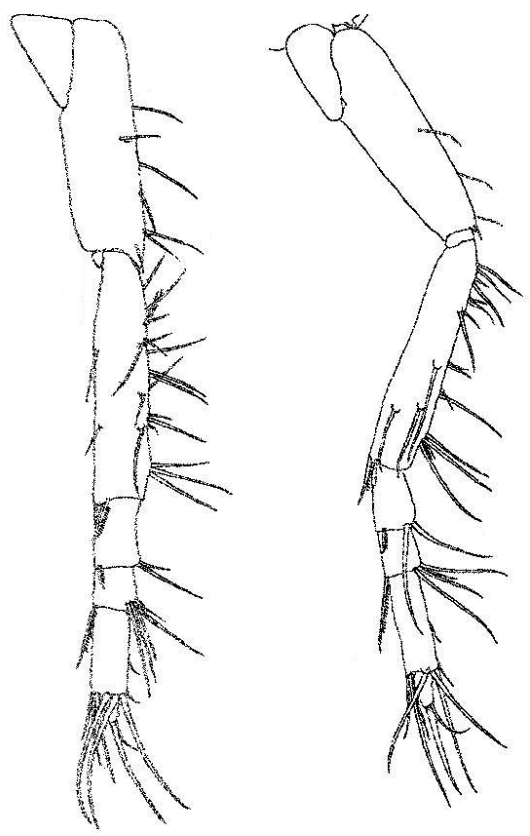

Figure 2. Mysidopsis gemina n. sp., adult female (D, F), male (A-C, E, G). A, thoracic endopod 1 with enlargement of distal end; B, thoracic endopod 2 with enlargement of distal end; $C$, thoracic endopod 3 with enlargement of serrate seta; D-G, thoracic endopods 4-7. Scale: A-G, $0.1 \mathrm{~mm}$. 


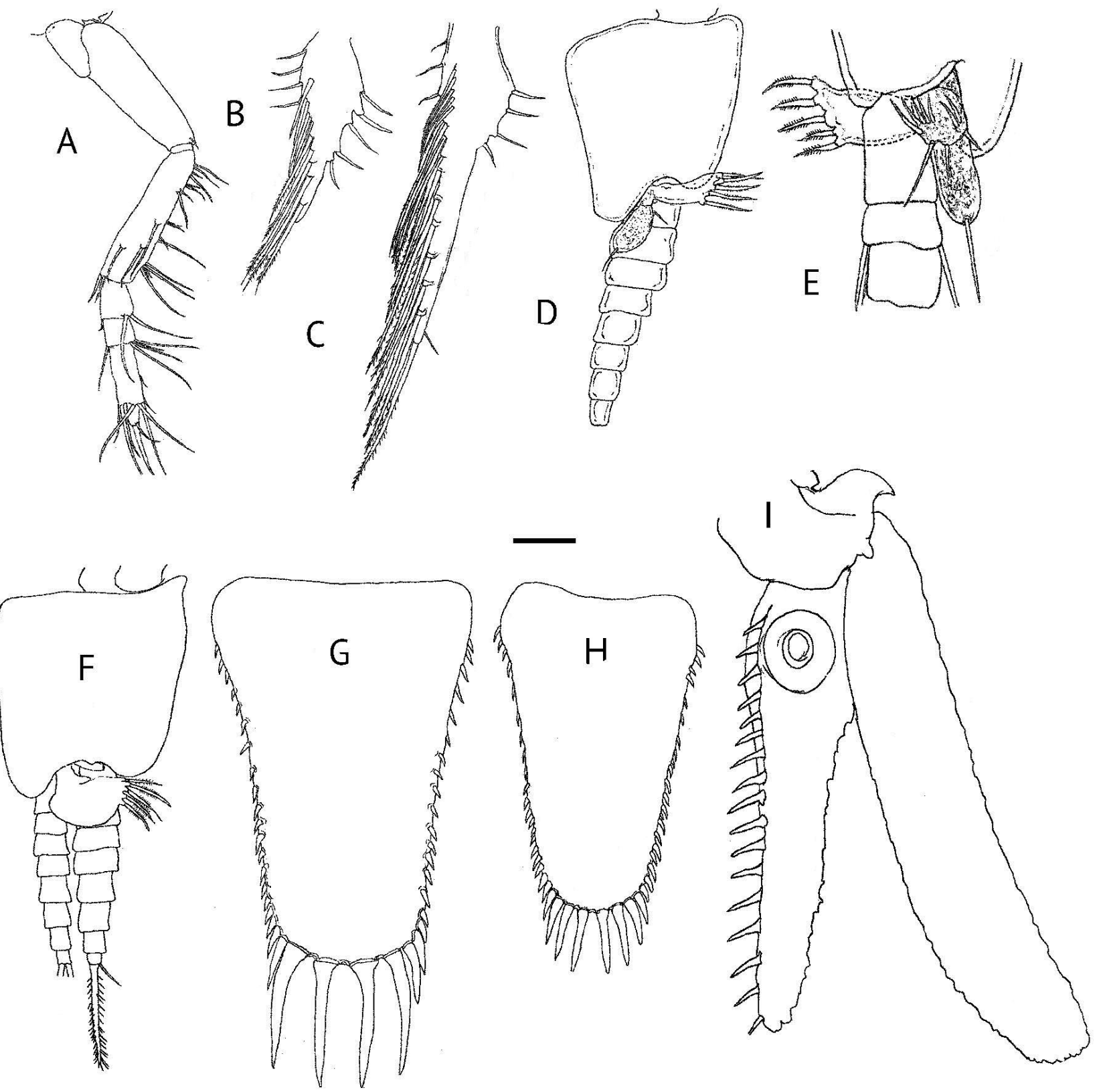

Figure 3. Mysidopsis gemina n. sp., adult female (B, C, G), male (A, D-F, H, I). A, thoracic endopod 8; B, pleopod 4, anterior view; C, pleopod 5, anterior view; D, pleopod 1, posterior view; E, pleopod 1, anterior view; F, pleopod 4, posterior view; G, telson; H, telson; I, uropod. Scale: A-D, F-I, $0.1 \mathrm{~mm}$; E, $0.05 \mathrm{~mm}$.

dorsal base of telson, and posterior-most pair of oostegites.

Etymology. The species name is a Latin adjective with female gender referring to the similarity of the new species to its Atlantic cognate, $M$. furca Bowman, 1957.

Habitat. Collected from sandy beaches in depths of 0.5 to $1.0 \mathrm{~m}$. 
Type locality. Costa Rica, Puntarenas, Playa Caldera $\left(09^{\circ} 92^{\prime} 75^{\prime \prime} \mathrm{N} 84^{\circ} 71^{\prime} 64^{\prime \prime} \mathrm{W}\right)$, grey sand beach, depth $1 \mathrm{~m}$.

Distribution. At present known only from the provinces of Guanacaste and Puntarenas along the Pacific coast of Costa Rica.

Remarks. Mysidopsis gemina n. sp. has its closest morphological affinities with $M$. furca. These two species, respectively, appear to represent Eastern Pacific and Western Atlantic cognate or sister species. Both differ from other known members of the genus Mysidopsis by the distinctive sexual dimorphism expressed by their telsons. The new Costa Rican species is distinguished from $M$. furca by a variety of characters, including the (1) acutely pointed triangular rostrum (blunt in $M$. furca), (2) male pleopods 2-5 with enlarged pseudopodal lobes on the endopods (lobes normally developed in M.furca), (3) male first pleopod having a biarticulated endopod (uniarticulate in $M$. furca), and (4) fewer number of spiniform setae (16-20) on the uropodal endopod (20-45 in $M$. furca). For additional morphological details for these and other characters for distinguishing the two sister species, see Tab. 1 .

Table 1. Comparison of diagnostic characters of Mysidopsis furca Bowman, 1957 and Mysidopsis gemina n. sp.

\begin{tabular}{|c|c|c|}
\hline Characters & M. furca & M. gemina n. sp. \\
\hline Anterior dorsal margin of rostrum & $\begin{array}{l}\text { bluntly triangular, barely reaching article } 1 \\
\text { of antennular peduncle }\end{array}$ & $\begin{array}{l}\text { acutely pointed triangular, reaching distal end } \\
\text { of article } 1 \text { of antennular peduncle }\end{array}$ \\
\hline Antennal scale, length: greatest width & $4.0-4.2$ & $5.5-7.0$ \\
\hline Male pleopod 1 & endopod 1 -articulated & endopod 2-articulated \\
\hline Male pleopod 4 & exopod 7-articulated & exopod 8-articulated \\
\hline Male pleopods $1-5$, pseudobranchial lobe & lobes normally developed & $\begin{array}{l}\text { pleopod } 1 \text { lobe normally developed; pleopods } 2-5 \\
\text { lobes enlarged }\end{array}$ \\
\hline Spiniform setae on uropodal endopod & $20-45$ & $16-20$ \\
\hline \multicolumn{3}{|l|}{ Telson: } \\
\hline - Length: greatest width & F: $1.1-1.2 ; \mathrm{M}: 1.4$ & F: $1.4-1.6 ; \mathrm{M}: 1.5-1.6$ \\
\hline - Lateral margins & $\begin{array}{l}\text { F: markedly concave; } \\
\text { M: moderately concave }\end{array}$ & $\begin{array}{l}\text { F: moderately concave; } \\
\text { M: moderately concave }\end{array}$ \\
\hline - Lateral setae (excluding apical setae) & F: $7-12 ;$ M- $10-14$ & F: $17-20 ; M: 20-23$ \\
\hline - Emargination between apical inner setae & present & absent \\
\hline - Pairs of apical spiniform setae & $F: 2 ; M: 2$ & $\mathrm{~F}: 2 ; \mathrm{M}: 3$ \\
\hline - Length of inner apical setae: telson length & F: $0.5 ; \mathrm{M}: 0.2-0.25$ & F: $0.3 ; \mathrm{M}: 0.2$ \\
\hline $\begin{array}{l}\text { - Length of inner apical setae: adjacent apical } \\
\text { setal length }\end{array}$ & F: $1.0-1.2 ; \mathrm{M}: 2.0-2.2$ & F: $1.0 ; \mathrm{M}: 1.0$ \\
\hline $\begin{array}{l}\text { - Length of outer-most apical setae: most } \\
\text { posterior lateral setal length }\end{array}$ & F: $3.0-8.5 ; \mathrm{M}: 1.7-2.2$ & F: $1.7-2.2 ; \mathrm{M}: 1.4-1.7$ \\
\hline References & $\begin{array}{l}\text { Bowman (1957); Brattegard (1969); } \\
\text { Stuck et al. (1979a; 1979b); Heard et al. (2006) }\end{array}$ & \\
\hline
\end{tabular}

F: Female; M: Male

\section{Discussion}

With the inclusion of Mysidopsis gemina n. sp., 51 nominal species and one subspecies currently compose the genus Mysidopsis (see Mees and Meland, 2012; present study), which represents the largest and most diverse of the other 30 genera presently composing the subfamily Leptomysinae. Males for 43 of the nominal species of Mysidopsis have been described. Within this genus, as well as within the subfamily Leptomysinae, the simultaneous combination of the (1) telson exhibiting distinctive sexual dimorphism, (2) first pleopod of the male having biarticulated endopod, and (3) male pleopods 2-5 with endopods having large plate-like pseudopodia (exites) appears to be unique to M. gemina. Table 2 presents a synopsis of the geographical distribution of these characters among species in the three tribes (Afromysini, Leptomysini, and Mysidopsini) of the Leptomysinae. 
Table 2. Geographic distribution of the species described with three distinctive characters (sexually dimorphic telson, male pleopod 1 with biarticulated endopod, male pleopodal endopod with enlarged pseudopodia) among the three tribes of the subfamily Leptomysinae (including new Costa Rican species).

\begin{tabular}{|c|c|c|}
\hline Character & Distribution & Reference \\
\hline \multicolumn{3}{|l|}{ Sexually dimorphic telson } \\
\hline \multicolumn{3}{|l|}{ - Tribe Afromysini } \\
\hline Doxomysis acanthina Talbot, 1997 & Australia & Talbot, 1997 \\
\hline D. australiensis (W. Tattersall, 1940) & Australia; South Africa (?) & $\begin{array}{l}\text { Băcescu and Udrescu, 1982; Talbot, 1997; } \\
\text { Wooldridge and Mees, } 2000\end{array}$ \\
\hline D. longiura Pillai, 1963 & India; South China Sea & Pillai, 1963, 1964; Talbot, 1997 \\
\hline D. spinata Murano, 1990 & Australia & Talbot, 1997 \\
\hline Neodoxomysis elongata Murano, 1999 & Sahul Shelf & Murano, 1999 \\
\hline Pseudoxomysis caudaensis Nouvel, 1973 & Vietnam, Java, Indonesia & Nouvel, 1973; Murano, 2001 \\
\hline Tenagomysis tasmaniae Fenton, 1991b & Tasmania; Bass Strait & Fenton, 1991b \\
\hline \multicolumn{3}{|l|}{ - Tribe Leptomysini } \\
\hline Paraleptomysis apiops (Sars, 1877) & Mediterranean Sea & Wittmann, 1986 \\
\hline P. banyulensis (Bačescu, 1966) & Mediterranean Sea & Wittmann, 1986 \\
\hline P. dimorpha Wittmann, 1986 & Eastern Atlantic & Wittmann, 1986 \\
\hline P. sinensis Liu \&Wang, 1983 & South China Sea & Liu and Wang, 1983; Wittmann, 1986 \\
\hline P. xenops (W. Tattersall, 1922) & Indian Ocean; Indonesia; South China Sea & Wittmann, 1986 \\
\hline \multicolumn{3}{|l|}{ - Tribe Mysidopsini } \\
\hline Mysidopsis gemina n. sp. & Eastern Pacific, Costa Rica & Present study \\
\hline M. furca Bowman, 1957 & U. S. Atlantic coast; Gulf of Mexico & Heard et al., 2006 \\
\hline M. kenyana Băcescu and Vasilescu, 1973 & Kenya & Băcescu and Vasilescu, 1973 \\
\hline M. onofrensis Băcescu and Gleye, 1979 & Eastern Pacific, California & Băcescu and Gleye, 1979 \\
\hline \multicolumn{3}{|l|}{ Male pleopod 1- biarticulated endopod } \\
\hline \multicolumn{3}{|l|}{ - Tribe Afromysini } \\
\hline Doxomysis australiensis & Australia; South Africa (?) & $\begin{array}{l}\text { Bačescu and Udrescu, 1982; Wooldridge and } \\
\text { Mees, } 2000\end{array}$ \\
\hline \multicolumn{3}{|l|}{ - Tribe Mysidopsini } \\
\hline Mysidopsis gemina $\mathrm{n} . \mathrm{sp}$ & Eastern Pacific, Costa Rica & Present study \\
\hline M. abbreviata Wittmann and Griffiths, 2018 & South Africa & Wittmann and Griffiths, 2018 \\
\hline M. buffaloensis Wooldridge, 1988 & South Africa & $\begin{array}{l}\text { Wooldridge, } 1988 \text {; Wittmann } \\
\text { and Griffiths, } 2018\end{array}$ \\
\hline M. indica W.Tattersall, 1922 & India & Wittmann and Griffiths, 2018 \\
\hline M. similis (Zimmer, 1912) & South Africa & Wittmann and Griffiths, 2018 \\
\hline M. zsilaveczi Wittmann and Griffiths, 2014 & South Africa & Wittmann and Griffiths, 2018 \\
\hline \multicolumn{3}{|c|}{ Male pleopods- endopods with enlarged pseudopodia } \\
\hline \multicolumn{3}{|l|}{ - Tribe Afromysini } \\
\hline Iimysis orientalis (Ii, 1937) & Japan & Ii, 1937,1964 \\
\hline Promysis orientalis Dana, 1852 & $\begin{array}{l}\text { South China Sea, western Pacific, Philippines, } \\
\text { Australia }\end{array}$ & Tattersall, 1936; Ii, 1964 \\
\hline $\begin{array}{l}\text { Pseudobranchiomysis arenae Carcedo, Fiori, and } \\
\text { Hoffmeyer, } 2013\end{array}$ & Argentina & Carcedo et al., 2013 \\
\hline \multicolumn{3}{|l|}{ - Tribe Leptomysini } \\
\hline Antichthomysis notidana Fenton, 1991a & Tasmania & Fenton, 1991a \\
\hline \multicolumn{3}{|l|}{ - Tribe Mysidopsini } \\
\hline Mysidopsis gemina n. sp. & Eastern Pacific, Costa Rica & Present study \\
\hline M. abbreviata & South Africa & Wittmann and Griffiths, 2018 \\
\hline M. cultrata Brattegard, 1973 & Caribbean & Wittmann and Griffiths, 2014 \\
\hline M. indica & India & Wittmann and Griffiths, 2014 \\
\hline M. zsilaveczi & South Africa & Wittmann and Griffiths, 2014 \\
\hline
\end{tabular}


Telsonic sexual dimorphism within the subfamily Leptomysinae. Within the tribe Mysidopsini, Mysidopsis is the only genus to exhibit sexually dimorphic telsons. Besides the striking sexual dimorphism exhibited by Mysidopsis gemina and M. furca, less significant telsonic sexual differences are reported for $M$. kenyana Băcescu and Vasilescu, 1973 and M. onofrensis Băcescu and Gleye, 1979. In M. onofrensis adult males (5.5-6 mm) have 18-23 lateral spiniform setae on the telson margin; whereas, females (4.6-6.0 mm) with incipient marsupia bear 25-28 such marginal setae. For M. kenyana, adult females have slightly longer subapical spiniform setae than those of the males (see Băcescu and Vasilescu, 1973; Băcescu and Gleye, 1979).

Sexually dimorphic telsons occur in members of the other two tribes of the Leptomysinae, the Afromysini and Leptomysini. It is represented in four (Doxomysis Hansen, 1912, Neodoxomysis Murano, 1999, Pseudoxomysis Nouvel, 1973 and Tenagomysis Thomson, 1900) of the 19 genera composing the tribe Afromysini, and one (Paraleptomysis Liu and Wang, 1983) of the six genera within the tribe Leptomysini.

Presence of a biarticulated endopod on the first male pleopod. Apparently, only two genera of leptomysids have a first male pleopod with a biarticulated endopod. Within the tribe Mysidopsini, in addition to the new species, five species of Mysidopsis exhibit this character (i.e., M. abbreviata Wittmann and Griffiths, 2018; $M$. buffaloensis Wooldridge, 1988 (see Wittmann and Griffiths, 2018); M. indica W. Tattersall, 1922; $M$. similis (Zimmer, 1912); and M. zsilaveczi Wittmann and Griffiths, 2014).

Besides the genus Mysidopsis, this male character has been documented for only one other leptomysid species, Doxomysis australiensis (W. Tattersall, 1940) belonging to the tribe Afromysini. In their illustration (Fig. 5E) of the first male pleopod of $D$. australiensis, Bačescu and Udrescu (1982) clearly show a biarticulated endopod; however, in their description of this structure they incorrectly designated it as a reduced "exopod." There is the caveat that this character may have been overlooked in earlier descriptions of Mysidopsis and the other members of the subfamily Leptomysinae.
Presence of enlarged pseudopodia (exites) on endopod of male pleopods. Within the tribe Mysidopsini, males of five species of Mysidopsis are reported as having some or all pleopodal endopods bearing expanded pseudopodia. As for M. gemina, males of M. abbreviata and $M$. indica have enlarged pseudopodia on pleopods $2-5$, whereas these structures are found on pleopods 1-5 for M. zsilaveczi and M. cultrata Brattegard, 1973 (see Wittmann and Griffiths, 2014; 2018).

The occurrence of distinct, enlarged "plate-like" pseudopodia (exites) is shared by four other leptomysid taxa, each representing a different genus. Within the tribe Afromysini, Iimysis orientalis (Ii, 1937), Promysis orientalis Dana, 1852 and Pseudobranchiomysis arenae Carcedo, Fiori and Hoffmeyer, 2013 are characterized by having male pleopods $2-4,2-5$, and $1-5$, respectively, with enlarged pseudopodia. Ii (1937) described the pseudopodia of the former species as "more or less swollen at the posterior margin"; however, they do not appear to be overly swollen in his illustrations (Ii, 1937: figs. 26, 27). The remaining species, Antichthomysis notidana Fenton, 1991a, belonging to the tribe Leptomysini, is described as having enlarged pseudopodia on pleopods 2-5.

Final remarks. Within the subfamily Leptomysinae, Mysidopsis gemina n. sp. appears to exhibit via its telson and male pleopods (i.e., pleopod 1 having biarticulate endopod, plate-like pseudopodia on pleopods 2-5) the greatest diversity of sexually dimorphic characters. The specific combination of these characters is unique to M. gemina, but not individually, and one or two of these traits are shared by other Mysidopsis species and some of the other genera within its subfamily. These traits appear to occur in no particular systematic pattern, making it difficult to assess whether this is due to plesiomorphic or apomorphic expressions (e.g., homoplasy/convergences).

As outlined in Tab.2, the most common occurrences of these characters appear to be within the Indo-Pacific Region, but this incipient pattern may be due to an artifact of sampling, or by their being overlooked or undocumented in earlier species descriptions. Notwithstanding, their possible systematic importance may have to be resolved in future molecular phylogenetic and morphologic studies. 


\section{ACKNOWLEDGEMENTS}

We thank Odalisca Breedy and Jorge Cortes for their assistance with field trips and Robin Overstreet for advice with etymology. Material was collected under permits 181-2010-SINAC, 001-2012-SINAC, SINACSE-GASP-PI-R-072-2014. This is a contribution from the Zoology Museum of Biology School of the University of Costa Rica.

\section{References}

Băcescu, M. 1966. Contribution à l'étude du genre Leptomysis de trois taxons nouveaux: Leptomysis peresi n. sp., L. apiops banyulensis n. ssp. et L. bürgii n. sp. Viet et Milieu, 17: 121-142.

Băcescu, M. 1968. Contribution to the knowledge of the Gastrosaccinae psammobionte of the Tropical America, with the description of a new genus (Bowmaniella n. g.) and three new species of its frame. Travaux du Muséum d'Histoire naturelle "Grigore Antipa", 8: 355-373.

Băcescu, M. and Gleye. L.G. 1979. New Mysidacea from the Californian waters. Travaux du Muséum d'Histoire Naturelle "Grigore Antipa", 20: 130-141.

Băcescu, M. and Udrescu, A. 1982. New contribution to the knowledge of the Mysidacea from Australia. Travaux $d u$ Muséum d'Histoire Naturelle "Grigore Antipa", 24: 79-96.

Băcescu, M. and Vasilescu, E. 1973. New benthic mysids from the littoral waters of Kenya: Mysidopsis kenyana n. sp. and Nouvelia natalensis mombasae n. g., n. sp. Revue Roumaine de Biologie Série de Zoologie, 18: 249-256.

Bowman, T.E. 1957. A new species of Mysidopsis (Crustacea: Mysidacea) from the southeastern coast of the United States. Proceedings of the United States National Museum, 107: 1-7.

Brattegard, T. 1969. Marine biological investigations in the Bahamas 10. Mysidacea from shallow water in the Bahamas and Southern Florida. Part 1. Sarsia, 39: 17-106.

Brattegard, T. 1973. Mysidacea from shallow water on the Caribbean coast of Colombia. Sarsia, 54: 1-66.

Carcedo, C.; Fiori, S. and Hoffmeyer, M. 2013. Pseudobranchiomysis arenae, a new genus and species of Leptomysinae (Crustacea: Mysida) in Argentinian sandy beaches. Zootaxa, 3647: 479487.

Dana, J.D. 1852. Crustacea. Part I. United States Exploring Expedition. During the years 1838, 1839, 1840, 1841, 1842. Under the command of Charles Wilkes, U.S.N., Vol. 13. Philadelphia, C. Sherman, 685p.

Dexter, D.M. 1974. Sandy-beach fauna of the Pacific and Atlantic coasts of Costa Rica and Colombia. Revista de Biología Tropical, 22: 51-66.

Fenton, G.E. 1991a. Description of Antichthomysis notidana n.g. n.sp. from southern Tasmania (Crustacea: Mysidacea: Leptomysini). Hydrobiologia, 224: 71-75.

Fenton, G.E. 1991b. Three new species of Tenagomysis from the coastal waters of south-eastern Tasmania (Crustacea:
Mysidae: Mysinae: Leptomysini). Memoirs of the Museum of Victoria, 52: 325-335.

Hansen, H.J. 1912. Report on the scientific results of the expedition to the eastern tropical Pacific, in charge of Alexander Agassiz, by the U. S. Fish Commission steamer "Albatross", from October, 1904 to March, 1905. The Schizopoda. Memoirs of the Museum of Comparative Zoology Harvard. 35: 173-296.

Heard, R.W. and Price, W.W. 2006. Revision of Bowmaniella sensu Băcescu, 1968 (Crustacea: Mysida: Gastrosaccinae): a taxonomic conundrum. Zootaxa, 1269: 1-29.

Heard, R.W.; Price, W.W.; Knott, D.M.; King R.A. and Allen, D.M. 2006. A taxonomic guide to the mysids of the South Atlantic Bight. NOAA Professional Paper NMFS 4: 1-37.

Ii, N. 1937. Studies on Japanese Mysidacea III. Descriptions of four new species belonging to tribes, Leptomysini and Erythropini. Japanese Journal of Zoology, 7: 191-209.

Ii, N. 1964. Fauna Japonica, Mysidae (Crustacea). Tokyo, Biogeographical Society of Japan, 610p.

Liu, R. and Wang, S. 1983. On a new genus of Mysidacea, Paraleptomysis gen. nov. from the South China Sea. Oceanologia et Limnologia Sinica, 14: 203-210.

Mees, J. and Meland, K. (eds) (2012 onwards). World List of Lophogastrida, Stygiomysida and Mysida. Available at http:// www.marinespecies.org/mysidacea. Accessed on 26 April 2019.

Murano, M. 1990. Three new leptomysids (Mysidacea) from Northern Australia. Crustaceana 59: 231-244.

Murano, M. 1999. A new genus, Neodoxomysis (Crustacea: Mysidacea: Mysidae: Leptomysini), with description of two new species. Proceedings of the Biological Society of Washington, 112: 352-361.

Murano, M. 2001. The genus Pseudoxomysis (Crustacea: Mysidacea: Mysidae: Leptomysini), with description of a new species from the Timor Sea. Proceedings of the Biological Society of Washington, 114: 887-896.

Nouvel, H. 1973. Pseudoxomysis caudaensis n. gen., n. sp., Crustacé Mysidacé (Leptomysini) de la Mer de Chine méridionale. Bulletin de la Société d'Histoire Naturelle de Toulouse, 109: 131-141.

Pillai, N.K. 1963. On a new mysid from the inshore waters of the Kerala coast. Journal of Marine Biological Association of India, 5: 258-262.

Pillai, N.K. 1964. Report on the Mysidacea in the collection of the Central Marine Fisheries Research Institute, Mamdapam Camp, South India - Part 1. Journal of the Marine Biological Association of India, 6: 1-41.

Price, W.W. 2004. An annotated checklist for the order Mysida (Crustacea: Malacostraca: Peracarida) from the Pacific coasts of the Americas (Alaska to Chile). p. 53-77. In: M. E. Hendrickx (ed), Contributions to the Study of East Pacific Crustaceans, Vol. 3. Instituto de Ciencies del Mar y Limnologia, National Autonomous University of Mexico.

Price, W.W.; Heard, R.W. and Vargas, R. 2009. Shallow water mysids. p. 229-236. In: I.S. Wehrtmann and J. Cortés (eds), Marine biodiversity of Costa Rica, Central America. Monographiae Biologicae, 86. New York, Springer. 
Sars, G.O. 1864. Beretning om en i Sommeren 1863 foretagen Zoologisk Reise i Christianias og Trondjhems Stifter. Nyt Magazin for Naturvidensskaberne, 13: 225-260.

Sars, G.O. 1877. Nye bidrag til kundskaben om Middelhavets i Invertebratfauna I. Middelhavets Mysider. Archiv for Mathematik og Naturvidenskab Christiania, 2: 10-119.

Smith, S.I. 1870. Notes on American Crustacea, No. 1, Ocypodoidea. Transactions of the Connecticut Academy of Arts and Sciences, 2: 113-176.

Stuck, K.C.; Perry H.M. and Heard, R.W. 1979a. An annotated key to the Mysidacea of the North central Gulf of Mexico. Gulf Research Reports, 6: 225-238.

Stuck, K.C.; Perry H.M. and Heard, R.W. 1979b. Records and range extensions of Mysidacea from coastal and shelf waters of the eastern Gulf of Mexico. Gulf Research Reports, 6: 239-248.

Talbot, M.S. 1997. Doxomysis acanthina, a new leptomysinid (Crustacea: Mysidacea) from the northern Barrier Reef, Australia, with extensions to the known distributions of $D$. australiensis W.M. Tattersall, 1940 and D. spinata Murano, 1990 and a key to the genus Doxomysis. Proceedings of the Biological Society of Washington, 110: 426-438.

Tattersall, O.S. 1967. A survey of the genus Heteromysis (Crustacea: Mysidacea) with descriptions of five new species from tropical coastal waters of the Pacific and Indian Ocean, with a key for the identification of the known species of the genus. Transactions of the Zoological Society of London, 31: 157-193.

Tattersall, W.M. 1922. Indian Mysidacea. Records of the Indian Museum, 24: 445-504.

Tattersall, W.M. 1936. The Zooplankton. V. The occurrence and seasonal distribution of the Mysidacea and Euphausiacea. p. 277-289. In: Scientific Reports of the Great Barrier Reef Expedition 1928-1929, v. 2. London, British Museum (Natural History).
Tattersall, W.M. 1940. Report on a small collection of Mysidacea from the coastal waters of New South Wales. Records of the Australian Museum, 20: 327-340.

Tattersall, W.M. 1951. A review of the Mysidacea of the United States National Museum. Bulletin of the United States National Museum, 201: 1-292.

Thomson, G.M. 1900. On some New Zealand Schizopoda. Journal of the Linnean Society of London, Zoology, 27: 482-286.

Wittmann, K.J. 1986. A revision of the genus Paraleptomysis Liu \& Wang (Crustacea: Mysidacea). Sarsia, 71: 147-160.

Wittmann, K.J. 2009. Revalidation of Chlamydopleon aculeatum Ortmann, 1893, and its consequences for the taxonomy of Gastrosaccinae (Crustacea: Mysida: Mysidae) endemic to coastal waters of America. Zootaxa, 2115: 21-33.

Wittmann, K.J. and Griffiths, C.L. 2014. Description of the 'stargazer mysid' Mysidopsis zsilaveczi sp. nov. (Mysida: Mysidae: Leptomysinae) from the Cape Peninsula, South Africa. Crustaceana, 87: 1411-1429.

Wittmann, K.J. and Griffiths, C.L. 2018. A new species of Mysidopsis G.O. Sars, 1864 from the Atlantic coast of South Africa, with supplementary descriptions of two additional species and notes on colour and feeding apparatus (Mysida: Mysidae). Journal of Crustacean Biology, 38: 215-234.

Wooldridge, T.H. 1988. A new species of Mysidopsis (Mysidacea) from coastal waters of Southern Africa and a key to the known species from the subcontinent. Annals of the South African Museum, 98: 93-103.

Wooldridge, T.H. and Mees, J. 2000. Doxomysis algoensis, a new mysid species (Crustacea, Mysidacea) from Algoa Bay (South Africa). Hydrobiologia, 421: 61-68.

Zimmer, C. 1912. Südwestafrikanische Schizopoden. In: L. Schultze (ed), Zoologische und anthropologische Ergebnisse einer Forschungsreise im westlichen und zentralen Südafrika. Denkschriften der Medizinisch-Naturwissenschaftlichen Gesellschaft zu Jena, 17: 1-11. 